\title{
OpenLISEM Flash Flood Modelling Application in Logung Sub-Catchment, Central Java
}

\author{
Fitrie Atviana Nurritasari, Sudibyakto and Victor G. Jetten
}

Received: 01092015 / Accepted: 20112015 / Published online: 15022016

๑ 2015 Faculty of Geography UGM and The Indonesian Geographers Association

\begin{abstract}
Juwana Catchment and Logung Sub-catchment in particular has been suffering several major past flood events with significant loss. This study conducted an assessment of flood risk by using OpenLISEM as physical soil and hydrological model to generate the single storm flash flood occurrences. The physical input data were collected from remote sensing image interpretation, field observation and measurement and literature review. There are three return periods chosen as scenarios that represent rainfall intensity in Logung Sub-Catchment. Model validation was done by adjusting initial moisture content and saturated hydraulic conductivity values to equate the calculated total discharge with the measured total discharge in several chosen dates. The results show increases in most of modeled hydrological parameter with respect to increasing of rainfall intensity.
\end{abstract}

Keywords: OpenLISEM, Flash flood modeling, Flood hazard assessment, Logung Sub-Catchment.

\begin{abstract}
Abstrak Juwana DAS dan Logung Sub-DAS khususnya telah menderita beberapa peristiwa banjir masa utama dengan kerugian yang signifikan. Penelitian ini dilakukan penilaian terhadap risiko banjir dengan menggunakan OpenLISEM sebagai tanah fisik dan model hidrologi untuk menghasilkan badai tunggal kejadian banjir bandang. Input data fisik yang dikumpulkan dari interpretasi citra penginderaan jauh, observasi lapangan dan pengukuran dan kajian literatur. Ada tiga periode ulang terpilih sebagai skenario yang mewakili intensitas curah hujan di Logung Sub-DAS. Validasi model dilakukan dengan menyesuaikan kadar air awal dan nilai-nilai konduktivitas hidrolik jenuh menyamakan total debit dihitung dengan total debit diukur beberapa tanggal yang dipilih dalam. Hasilnya menunjukkan peningkatan di sebagian besar parameter hidrologi dimodelkan sehubungan dengan meningkatnya intensitas curah hujan.
\end{abstract}

Kata Kunci: OpenLISEM, Banjir pemodelan flash, Penilaian bahaya banjir, Logung Sub-DAS.

\section{Introduction}

Flood is the most common natural disaster that occurred almost in every province in Indonesia every year which the frequency and intensity are increasing in the past decades. According to the Emergency Disasters Database, a global database compiled and managed by the Center for Research on the Epidemiology of Disasters (CRED) there were 168 flood incidents during 1953-2014 which caused 6,543 casualties and cost approximately more than 6.3 billion USD (EM-DAT, 2015). Every year the excessive discharge which also causing flood will be released to Juwana Catchment, a retarding basin of in Muria Mountain. Juwana Catchment lies over Pati, Kudus, Blora and Grobogan Regencies and Logung River is one of the tributary river in Juwana Catchment.

Increasing of urban development demands high

Fitrie Atviana Nurritasari

Geo-Information for Spatial Planning and Disaster Risk Management, Graduate School of Universitas Gadjah Mada

Email: fitrie.atviana@gmail.com

Sudibyakto

Faculty of Geography, Universitas Gadjah Mada, Indonesia

Victor G. Jetten

Applied Earth Science Department, Faculty of Geo-Information Science and Earth Observation, University of Twente, The Netherlands land conversion in the regencies in Juwana Catchment (Setiono 2006) along with the growth of agricultural and industrial sectors diminishes the swamp existence as retarding basin. The accumulation of sediment furthermore straitens the canals and decreases the river capacity, especially the Logung river to retard water and the overflow annually inundates the river basin (BBWS Pemali Juwana 2004; Istiarto and Wibowo 2007).

United Nation International Strategy for Disaster Reduction or UNISDR (2009) defined hazard as a dangerous phenomenon, substance, human activity or condition that may cause loss of life, injury or other health impacts, property damage, loss of livelihoods and services, social and economic disruption, or environmental damage. When the hazard occurrences result a serious disruption at those aspects it turns to be a flood disaster. The flood definition used in this study is the water inundation over the sub-catchment caused by overflowed water from Logung River. Thus flood hazard can be described as the potential inundation that may harm the populations, health, property, and natural resources and functions at the Logung Subcatchment.

The flood assessment as threat in Logung SubCatchment with agricultural sectors as predominant land cover is essential. This assessment gives better 
understanding in flood mechanism in Logung SubCatchment and also provides flood map according to several rainfall intensity scenarios.

Computer modeling of catchment hydrology is one approach can be conducted to simulate and identify the flood mechanism. One dimensional empirical flood open source model such as OpenLISEM, a physical grid based model that has been developed since 90s (the original LImburg Soil Erosion Model) (De Roo 1996; De Roo, Offermans et al. 1996; De Roo, Wesseling et al. 1996). This model can be used to simulate the runoff and identify the water flows process related to for example land use change scenario and designed rainfall scenario in a single rainfall event on a catchment scale. It models the hydrological processes in detail and requires many physical input data that can be vary spatially since this model will reacts well to spatial variability of input parameter.

Juwana Catchment is partially gauge catchment with limited field measurement. Logung Sub-Catchment (Figure 1) has quite good data availability including daily based rainfall and discharge data, yet limited soil information. There is only one spot of soil properties measurement in Sadang Village (BBWS Pemali Juwana 2004). Many flash flood modeling in partially gauge catchment is using US Army Corps Model, Hydrologic Engineering Center (HEC model) (Sui 2005; Koutroulis and Tsanis 2010) as well the study in Juwana catchment (Istiarto and Wibowo 2007; Santoso 2013).

This study conducted a sub-catchment based modeling, with detail physical hydrology simulations including simulation of interception, infiltration, overland flow, storage (surface and aboveground) and groundwater movement after the rainfall event. To adjust the model to the Logung condition, calibrations should be applied on initial moisture content and saturated hydraulic conductivity $\left(\mathrm{K}_{\mathrm{sat}}\right)$ (Hessel, Jetten et al. 2003; Jetten, Govers et al. 2003). There are several physical-hydrological steps simulated in OpenLISEM that represents what really happen on that field with very specific and detail input maps.

\section{The Methods}

Logung River is a tributary of Juwana Catchment where is located at $110^{\circ} 53^{\prime} 33.05^{\prime \prime}-110^{\circ} 57^{\prime} 32.35^{\prime \prime} \mathrm{E}$ and $6^{\circ} 38^{\prime} 16.81^{\prime \prime}-6^{\circ} 51^{\prime} 42.27^{\prime \prime}$. This sub-catchment lies at Kudus Regency with total of catchment area reaches $57.77 \mathrm{~km}^{2}$.

Logung Sub-Catchment consists of three predominant geological formation, leucite minerals formation, volcanic formations and alluvial plain. The upstream is a part of Muria Mountain with high elevation and steep slope $(>40 \%)$. The middle part of the catchment in the east side there is the Patiayam mountain as the paleo-volcanic formation that older than the formation of Muria Mountain (Mulyaningsih, Bronto et al. 2008). Like other areas in Central Java, Logung Sub-catchment has tropical climate with seasonal rainfall distribution and local interferences in variability due to Muria Mountain existence with the annual rinfall ranges from 1500 to $3000 \mathrm{~mm}$ per year.

A number of materials used in this study were obtained from observational data by several institutions (BBWS, BPDAS, PSDA, BMKG) and previous study Santoso (2013) held in Juwana Catchment. Meanwhile, some other data and primary information were collected from field work. Table 1 contains the materials, sources of materials and its remarks.

This study of flood risk assessment consists of several main steps, they are (1) field data collections including soil sampel collections and land cover observation, (2) rainfall analysis and flood model input data collections and (3) flood hazard modeling.

The soil samples taken on field are according to the slope and geological formation types by using overlay method, mapping unit of soil map is resulted. There

Table 1. Materials Used in the Study, Sources and Remarks

\begin{tabular}{|c|c|c|}
\hline Material & Source & Remarks \\
\hline Daily rainfall data 1991-2012 & $\begin{array}{l}\text { Public Work Department (PSDA of } \\
\text { Central Java Province and PSDA of } \\
\text { Kudus Regency) }\end{array}$ & $\begin{array}{l}\text { Consists of } 5 \text { stations Mostly } \\
\text { in } 2010 \text { for all stations the data } \\
\text { was missing }\end{array}$ \\
\hline Soil Map, 2010 & BPDAS Pemali-Juwana & Shapefile \\
\hline Slope Map, 2010 & BPDAS Pemali-Juwana & $\begin{array}{l}\text { Shepefile derived from topo- } \\
\text { graphical map }\end{array}$ \\
\hline DEM, 2010 & Bakosurtanal & $\begin{array}{l}\text { Shapefile derived from con- } \\
\text { tour map }\end{array}$ \\
\hline Geological Map, 2010 & BPDAS Pemali-Juwana & Shapefile \\
\hline $\begin{array}{l}\text { Catchment and sub-catchment } \\
\text { boundary }\end{array}$ & BBWS Pemali Juwana & Shapefile \\
\hline $\begin{array}{l}\text { Fine resolution remote sensing } \\
\text { imagery }\end{array}$ & Bing Image & $\begin{array}{l}\text { On September } 2012 \text { to build } \\
\text { land cover map }\end{array}$ \\
\hline
\end{tabular}




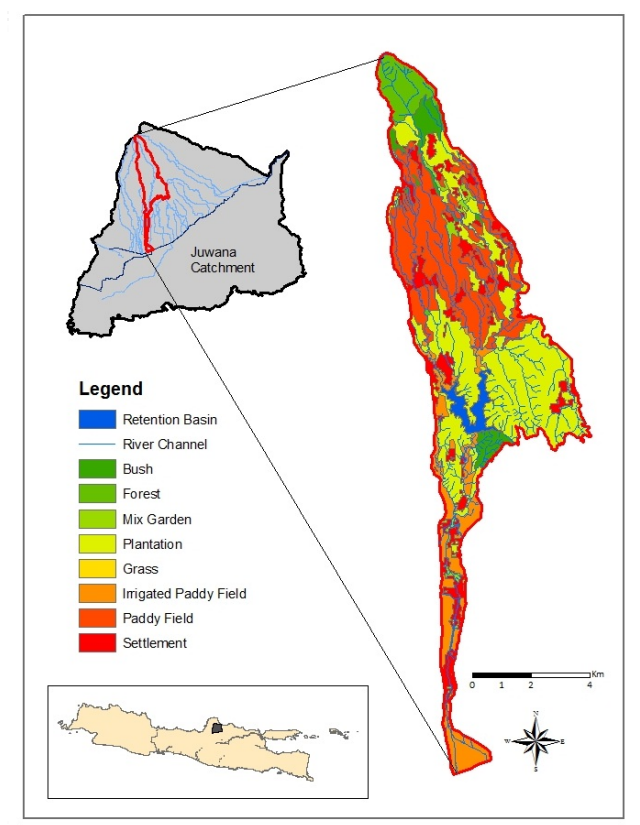

Figure 1. Location of Logung Sub-catchment

are total 25 soil samples taken from the field, and 26 addition points for land cover observations distributed in the field. The soil sample points are distributed purposively according to the total area of the mapping unit. The soil samples were analyzed on Soil Laboratory of Agriculture and Technology Agency of Yogyakarta Province during December 2013. The other parameters are derived by using Soil Water Characteristics (SWC) software with Saxton Formula (Saxton and Rawls 2006). Those parameters are including wilting point, field capacity, saturation, available water, saturated hydraulic conductivity and metric bulk density. The inputs of this software are fraction of soil texture and the organic matter of each mapping unit.

OpenLISEM requires many input data at raster based maps to conduct a single physical rainfall-runoff modeling. Those maps individually are derived from different base map with different method and collected informations. The entire raster input maps are produced by using PCRaster 4.4, while the initial DEM map and any other mapping and land cover delineation processes were done in GIS Software.

Method used to classified and identified land cover is using visual interpretation on high resolution image Bing Image on September 2012. To differentiate between land cover types existing land cover map (BBWS Pemali Juwana 2004; Widyana 2010) and field observations were used as validation. The vegetation parameters are mainly derived from land cover map that have been derived from previous step and verified by field observation, while for several parameters than not available at field or cannot be measured due to resource limitation, literature and reference will be used. Those mentioned parameters are settlement fraction, vegetation coverage fraction, vegetation height width of asphalt road and compacted soil (murrum road).

The LAI (leaf area Index) map is calculated from vegetation coverage fraction by using the Equation 1 (van Diepen, Wolf et al. 1989).

Leaf Area Index $=\ln (1-\mathrm{PER}) /(-0.4)$

$\mathrm{PER}=$ Vegetation coverage fraction $\left(\mathrm{m}^{2} / \mathrm{m}^{2}\right)$

Beside the rainfall data, most of the other catchment characteristic related maps are derived from DEM map which is calculated from Topographic map. Topographic map that used in this study is the map resulted by Geo-Spatial Information Agency (2010). By using Gumbel Type I method the historical rainfall data is extracted to identify the frequency distribution. The hourly rain data input is derived from disaggregation from daily rainfall by using Mononobe Method. Equation 2 was used (Sosrodarsono and Takeda 1977) to calculate mean rainfall rate during $\mathrm{T}$ hours and the rainfall percentage for each hour.

$$
\mathrm{RT}=\mathrm{R} 24 / \mathrm{t} \cdot(\mathrm{t} / \mathrm{T})^{\wedge}(2 / 3)
$$

$\mathrm{RT}=$ Mean intensity rainfall in T hours ( $\mathrm{mm} /$ day)

$\mathrm{R} 24=$ effective rainfall in a day $(\mathrm{mm})$

$\mathrm{T}=$ time when the rainfall start

$\mathrm{t}=$ concentration time (assumption $\mathrm{t}=3$ )

At Logung Sub-catchment storm occurs averagely for 3 hours identified by BBWS (2004), hence $t=3$. To calculate rainfall for hourly bases the Equation 3 below was used.

$$
\mathrm{Rt}=(\mathrm{t} . \mathrm{RT})-(\mathrm{t}-1) \cdot\left(\mathrm{R}_{\mathrm{t}-1}\right)
$$

$\mathrm{Rt}=$ percentage average rainfall intensity in 1 day 
There are two classes of maps that related to soil surface and its properties that have been used in this study. The first class is maps were derived from land cover map because the property of soil surface is classified according to land cover type. The second class is the maps were derived from Mapping Unit for Soil Sample since the attribute value is obtained according to mapping unit or soil type. The first type of maps are including Manning's n map (n.map), random roughness map (rr.map), initial soil moisture content map (theta. map) and hard surface map (hardsurf.map), while the second type maps are saturated hydraulic conductivity map ( $\mathrm{k}_{\text {sat }}$ map), saturated soil moisture content map (thetas.map) and soil water tension map (psi.map). For other maps, the attribute values are assumed zero, since the related information is not available.

The input maps related to channel parameter and overland flow such as local drain direction of channel network (lddchan.map), channel gradient (changrad. map), Manning' $\mathrm{n}$ for the channel (chanman.map), width of the channel (chanwidt.map), channel cross section shape (chanside map) are mostly derived from channel map and ldd map.

The input map then were inputted to OpenLISEM with three return period scenario: 2 years, 10 years and 25 years. The validation will be designated based on the chosen case. The rainfalls of those chosen cases are the input of OpenLISEM simulation, meanwhile the observational discharge data then will be compared to the modeled discharge. The calibration will be done by adjusting the variable of Saturation Hydraulics conductivity and Initial Moisture, as the model is very sensitive to alteration of this two factors (Hessel, Jetten et al. 2003; Jetten, Govers et al. 2003).

\section{Result and Discussion}

The identification and separation between land cover is done based on visual interpretation on Bing Image and field observation. There were 51 points as point checkers distributed in the entire reachable area at the catchment. Those points were used as basic of land cover identification especially crops. There are eleven land cover types that could be recognized. They are arterial street, bare land, mining site, settlement, bush, forest, mix garden, orchards, paddy field, plantation and sugarcane.

Due to the limitation of point distribution and mixture of land cover type in the field which could not be distinguished even by using high resolution image, there was generalization made in the land cover separation. Mix garden and orchards are the land cover types with combination of several vegetations coverages. Land cover type directly affects hydrological process at field especially canopy storage and infiltration while its properties like as root depth and Manning's value will influence the infiltration and overland flow process. The soil depth, the zone that infiltration takes place is strongly related to vegetation's root depth (van
Noordwijk, Farida et al. 2003), while runoff occurs only when rainfall intensity exceeds the infiltration capacity of the soil. Hence the dense vegetation covers such as forest, plantation or even bush and shrub are expected to have higher infiltration capacity and reduce run off. However existence of crops as land cover such sugarcane, cassava, maize or paddy in reducing run off are not really proven. Thus crops as the predominant land cover probably can also increasing overland flow.

The Manning's coefficients are compiled after Chow (1959) and McCuen (1998). Not every land covers that used in this study has available Manning's $n$ coefficient on those two references hence the chosen coefficient values are the least similar land cover's Manning Values at the reference. The available information then will be compared to the channel Manning's n coefficient on Chow (1959).

Initial soil moisture and vegetation coverage for each land cover is compiled based on the research of Setiawan (2009). Setiawan measured all variables at Kreo Sub-catchment central java with similar soil type and vegetation coverage and relatively has similar climatic with Logung Sub-Catchment. Table 2 explains the attribute of land cover related to vegetation and soil properties and settlement density. These attributes then were used as OpenLISEM model input as in maps.

To identify the important soil properties needed in the modeling, 25 soil samples were taken and tested in Soil Lab in Agricultural Bureau, Yogyakarta Province. Table 3 contains the primary information as the result of various tests done in Laboratory and water temsion, while Table 2 also contains secondary information created from soil texture and soil organic matter as input through Soil Water Characteristic Software. Water tension is directly correlated with texture class in the term ability to hold water (Baver 1956; Buckman and Brady 1960). Soil properties like saturated Hydraulic conductivity, porosity and water tension were used in modeling as in attribute in soil maps. This information is very needed in physical-hydrological simulation precisely during infiltration process.

Even though it is also needed in infiltration process and classified as uttermost properties, Initial soil moisture was not measured in the field due to limited access and resources. Thus this information is obtained from reference based on previous study conducted in Kreo Sub-catchment Central Java (Setiawan 2009) This reference was chosen because of the similarity of soil type, geological formation and major land cover between Kreo Sub-catchment and Logung Subcatchment. Furthermore there are several land cover types that not available on the reference therefore the similar land covers were generalized and got the same initial soil moisture value.

Table 2 also comprises the initial soil moisture and random roughness for each land cover type. Random roughness is standard deviation of elevation level difference variation for each cell in the same 
land cover type according to the method proposed by Allamaras Burwell . These data were obtained from Digital Elevation Model of Logung Sub-catchment. The variation of random roughness that relatively small indicates there are no many depression that functioning as surface storage.

Frequency analysis is done to created several rainfall intensity scenarios. The chosen return periods are 2, 10, and 25 which estimated as more frequent intensity. Figure 2 is the graph of plotting position versus rainfall by Gumbel type I frequency method. The result is supposed to show increasing in inundation area correspond to increasing of rainfall intensity.

As inputs of the model, rainfall should be in the minute or hour based data but in Logung Subcatchment there is no automatic recorded rainfall data. To use Mononobe method, the preliminary assumption related to the rainfall type should be decided. Logung Sub-catchment generally has type of storms which takes place normally for 3 hours. Hence the distribution is made into ratio for each hour since the precipitation started. Table 4 showed the designed rainfall per Return period and table 5 includes the ratio and distribution of rainfall for each hour.

Mononobe method has been widely used in Indonesia especially by Ministry of Public Work in determine designed rainfall for multipurpose analysis. As a consequence by using this method with preliminary assumption, all data will be distributed into hourly rainfall with the uniform ratio. With relatively higher rainfall in the first hour of storm and the next two hour the rain will be depleted. This pattern will directly affect the hydrological process in the simulation. For example high rainfall in the first hour will increase the run off directly since the soil has already saturated. Even more when the initial soil moisture is quite high, soil will not infiltrate more water it cannot uphold.

As calibration input, four relatively uniform storm cases were chosen. The three storms are similar in daily rainfall, and quite vary for its observational discharge. The three rain inputs were simulated and the observational discharge were compared and used as validation parameter. Saturated hydraulic conductivity and initial soil moisture will be used as calibration

Table 2. Land Cover Attributes that Related to Vegetation and Soil Properties

\begin{tabular}{|c|c|c|c|c|c|c|c|c|}
\hline \multirow{3}{*}{$\begin{array}{l}\text { Land Cover } \\
4,5\end{array}$} & \multicolumn{4}{|c|}{ Vegetation Properties } & \multirow{2}{*}{$\begin{array}{l}\text { Average } \\
\text { Settle- } \\
\text { ment } \\
\text { Density }{ }^{3} \text {, }\end{array}$} & \multicolumn{2}{|c|}{ Soil Properties } & \multirow[b]{2}{*}{$\begin{array}{l}\text { Manning } \\
\text { Coeffi- } \\
\text { cient }^{7,8}\end{array}$} \\
\hline & $\begin{array}{l}\text { Average } \\
\text { Height }^{1,4}\end{array}$ & $\begin{array}{l}\text { Average } \\
\text { Root } \\
\text { Depth }^{1}\end{array}$ & $\begin{array}{l}\text { Coverage } \\
\text { Fraction }^{2}\end{array}$ & $\mathrm{LAI}^{3}$ & & $\begin{array}{l}\text { Initial soil } \\
\text { Moisture }^{2}\end{array}$ & $\begin{array}{l}\text { Random } \\
\text { Roughness }^{6}\end{array}$ & \\
\hline & $\mathrm{m}$ & $\mathrm{m}$ & $\mathrm{m}^{2} / \mathrm{m}^{2}$ & $\mathrm{~m}^{2} / \mathrm{m}^{2}$ & $\mathrm{~m}^{2} / \mathrm{m}^{2}$ & $\%$ & $\mathrm{~cm}$ & \\
\hline $\begin{array}{l}\text { Arteri- } \\
\text { al Street } \\
\text { (Smooth } \\
\text { Asphalt) }\end{array}$ & 0 & 0 & 0 & 0.00 & 0 & 0.46 & 1.046 & 0.013 \\
\hline $\begin{array}{l}\text { Bare land } \\
\text { (Open Sur- } \\
\text { face) }\end{array}$ & 0 & 0 & 0 & 0.00 & 0 & 0.43 & 0.189 & 0.018 \\
\hline Bush & 0.7 & 1.5 & 0.45 & 1.49 & 0 & 0.43 & 0.532 & 0.2 \\
\hline Forest & 15 & 2 & 0.9 & 5.76 & 0 & 0.47 & 0.535 & 0.8 \\
\hline Mining & 0 & 0 & 0 & 0.00 & 0 & 0.43 & 0.751 & 0.03 \\
\hline Mix Garden & 1.5 & 1.5 & 0.66 & 2.70 & 0 & 0.51 & 0.925 & 0.3 \\
\hline Orchards & 5 & 1.5 & 0.66 & 2.70 & 0 & 0.51 & 0.884 & 0.3 \\
\hline Paddy Field & 1 & 1 & 0.2 & 0.56 & 0 & 0.5 & 0.995 & 0.06 \\
\hline Plantation & 10 & 2 & 0.9 & 5.76 & 0 & 0.47 & 0.622 & 0.4 \\
\hline $\begin{array}{l}\text { Settlement } \\
\text { (Suburban } \\
\text { residential) }\end{array}$ & 0 & 0 & 0.45 & 1.49 & 0.8 & 0.46 & 1.171 & 0.055 \\
\hline $\begin{array}{l}\text { Sugarcane } \\
\text { (Matured } \\
\text { field crop) }\end{array}$ & 2 & 1.5 & 0.3 & 0.89 & 0 & 0.51 & 0.609 & 0.04 \\
\hline
\end{tabular}

Source: ${ }^{1}$ Allen, Pereira et al., (2000), ${ }^{2}$ Setiawan (2009), ${ }^{3}$ Equation proposed by van Diepen, Wolf et al., (1989), ${ }^{4}$ Field Observation, ${ }^{5}$ Visual Interpretation, ${ }^{6}$ Calculated based on Alamara Burwell random roughness definition, ${ }^{7}$ Chow (1959), ${ }^{8}$ McCuen (1998). 
parameters. The chosen storms for validation are rainfalls in 4 February 2002, 21 February 2008 and 8 January 2012.

Validation steps were carried out by comparing the simulated discharge with observational discharge at the same day. The calibration was done by changing two parameters initial soil moisture $\left(\right.$ Theta $_{\mathrm{i}}$ ) and saturated hydraulic conductivity $\left(\mathrm{K}_{\mathrm{sat}}\right)$. To change those two parameters, multiplication factor are used. Changing of parameters especially for $\mathrm{K}_{\text {sat }}$ should within tolerable boundaries that stated on Table 6 . Those $\mathrm{K}_{\text {sat }}$ value ranges of each soil textures could be guidance to calibrate the $\mathrm{K}_{\text {sat }}$ values. While for Theta, the adjusted soil moisture should not greater than 1 , since that means the soil is full filled by water content (very saturated).

The chosen storms for calibration and validation process are 4 February 2002, 21 February 2008 and 8 January 2012. Generally the initial simulated

Table 3. Mapping Units and Soil Properties

\begin{tabular}{llcrr}
\hline Mapping Unit Code & Texture Class ${ }^{1,3}$ & $\begin{array}{r}\text { Water Tension } \\
(\mathrm{cm})\end{array}$ & Porosity ${ }^{2}$ & $\begin{array}{r}\text { Sat. Hydraulic Con- } \\
\text { ductivity }^{3} \\
(\mathrm{~mm} / \mathrm{hr})\end{array}$ \\
\hline A1 & Clay Loam & 20.9 & 56.53 & 2.1 \\
A2 & Loam & 8.89 & 58.62 & 4.26 \\
C3 & Clay Loam & 20.9 & 59.17 & 4.44 \\
C4 & Clay Loam & 20.9 & 58.61 & 3.35 \\
C1 & Clay & 31.6 & 58.92 & 0.64 \\
C2 & Clay Loam & 20.9 & 56.05 & 3.37 \\
B3 & Clay Loam & 20.9 & 55.73 & 2.82 \\
B4 & Loam & 8.89 & 59.06 & 10.14 \\
B1 & Loam & 8.89 & 59.47 & 4.81 \\
B2 & Clay Loam & 20.9 & 54.94 & 3 \\
\hline
\end{tabular}

Source: ${ }^{1}$ Soil Lab analysis, ${ }^{2}$ Chen and Young (2006), ${ }^{3}$ Soil Water Characteristic Software Processing.

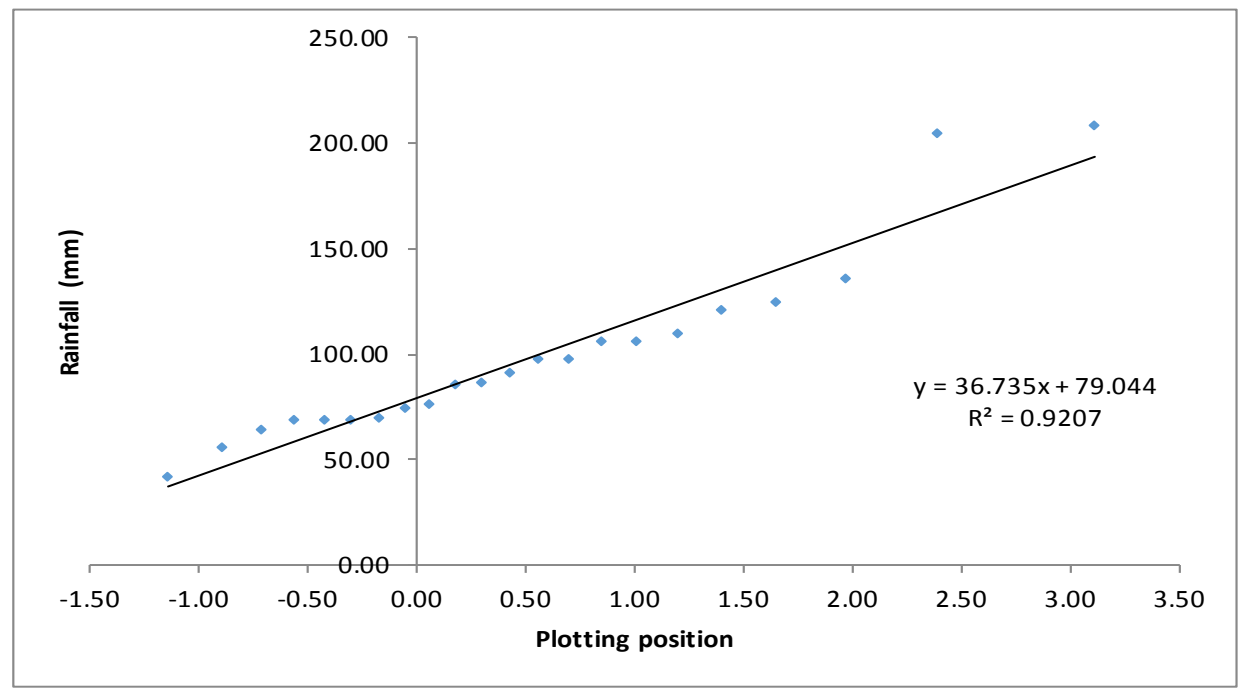

Figure 2. Gumbel Type I: plotting position vs rainfall

Table 4. Designed Rainfall per Return Period

\begin{tabular}{|c|c|c|c|}
\hline $\begin{array}{l}\text { Return Period } \\
\text { (years) }\end{array}$ & Left Probability (PL) & $\mathrm{x}$ (plotting position) & $\begin{array}{r}\mathrm{y} \text { (Rainfall) } \\
\mathrm{mm}\end{array}$ \\
\hline 2 & 0.500 & 0.37 & 92.51 \\
\hline 10 & 0.900 & 2.25 & 161.71 \\
\hline 25 & 0.960 & 3.20 & 196.54 \\
\hline
\end{tabular}


Table 5. Hourly Rainfall Rate for Every Return Period

\begin{tabular}{|c|c|c|c|c|c|}
\hline \multirow{2}{*}{$\mathrm{T}$} & \multirow{2}{*}{ Ratio } & \multirow{2}{*}{$\begin{array}{c}\text { Cumulative } \\
\text { ratio }\end{array}$} & \multicolumn{3}{|c|}{ Rainfall for each hour } \\
\hline & & & $2 \mathrm{yr}$ & $10 \mathrm{yr}$ & $25 \mathrm{yr}$ \\
\hline (hour) & $(\%)$ & $(\%)$ & & $\mathrm{mm}$ & \\
\hline 1 & 69.34 & 69.34 & 64.14 & 112.12 & 136.27 \\
\hline 2 & 18.02 & 87.36 & 16.67 & 29.14 & 35.42 \\
\hline 3 & 12.64 & 100.00 & 11.69 & 20.44 & 24.85 \\
\hline \multicolumn{3}{|c|}{ Designed Rainfall } & 92.51 & 161.71 & 196.54 \\
\hline
\end{tabular}

Table 6. Saturated Hydraulic Conductivity for Several Textures

\begin{tabular}{lr}
\hline Soil Texture & $\mathrm{K}_{\text {sat }}\left(\mathrm{mm} / \mathrm{hour}^{1,2}\right.$ \\
\hline Clay & $0.42-4.62$ \\
Clay Loam & $4.17-16.67$ \\
Loam & $12.50-41.67$ \\
\hline
\end{tabular}

Source: ${ }^{1}$ Clapp and Hornberger (1978), ${ }^{2} \mathrm{FAO}(1980)$

Table 7. Comparison of Initial Simulated and Observational Discharge

\begin{tabular}{lcccc}
\hline Date & Daily Rainfall & $\begin{array}{c}\text { Observational } \\
\text { Discharge }\end{array}$ & Simulated Discharge & $\Delta \mathrm{Q}$ \\
\hline 4-Feb-02 & $\mathrm{mm}$ & $\mathrm{m}^{3} / \mathrm{s}$ & $\mathrm{m}^{3} / \mathrm{s}$ & $\mathrm{m}^{3} / \mathrm{s}$ \\
21-Feb-08 & 63.70 & 16.5 & 23.6 & 7.1 \\
8-Jan-12 & 60.78 & 16.5 & 21.5 & 5.0 \\
\hline
\end{tabular}

Table 8. Comparison of Adjusted Discharge and Final Multiplying Factor of $\mathrm{K}_{\text {sat }}$ and Theta ${ }_{\mathrm{i}}$

\begin{tabular}{|c|c|c|c|c|c|c|}
\hline \multirow[t]{2}{*}{ Date } & \multirow[t]{2}{*}{ Daily Rainfall } & \multirow{2}{*}{$\begin{array}{c}\text { Observational } \\
\text { Discharge }\end{array}$} & \multirow{2}{*}{$\begin{array}{l}\text { Simulated } \\
\text { Discharge }\end{array}$} & \multicolumn{2}{|c|}{ Calibration } & \multirow[t]{2}{*}{$\Delta \mathrm{Q}$} \\
\hline & & & & $\mathrm{K}_{\text {sat }}$ & $\mathrm{K}_{\mathrm{sat}}$ & \\
\hline & $\mathrm{mm}$ & $\mathrm{m}^{3} / \mathrm{s}$ & $\mathrm{m}^{3} / \mathrm{s}$ & & & \\
\hline 4-Feb-02 & 63.70 & 16.5 & 16.5 & 1.43 & 0.88 & 0.01 \\
\hline 21-Feb-08 & 60.78 & 16.5 & 16.6 & 1.27 & 0.88 & 0.11 \\
\hline 8-Jan-12 & 68.62 & 12.2 & 12.4 & 1.89 & 0.59 & -0.20 \\
\hline \multicolumn{2}{|l|}{ Average } & & & 1.53 & 0.78 & \\
\hline \multicolumn{2}{|c|}{ Standard deviation } & & & 0.32 & 0.17 & \\
\hline
\end{tabular}

discharges produced by OpenLISEM are overestimated compared to the observational discharge. On Table 7 can be seen the comparison of initial discharge and the observational discharge for each date.

To decrease the runoff, It means the soil ability to absorb water should be amplified while the initial moisture at soil pores should be reduced. Hence the $\mathrm{K}_{\mathrm{sat}}$ parameter has to be enlarged and Theta ${ }_{\mathrm{i}}$ has to be lessened. After changing the $\mathrm{K}_{\text {sat }}$ and Theta ${ }_{\mathrm{i}}$ several times for each date to decrease the total runoff the final multiplying factor was found. Table 8 contains rainfalls, observational discharges, simulated discharges and final multiplying factors for each date.

The total runoff fraction is varying from $23.14 \%$ to $33.15 \%$, which is relatively low however at this point flood has actually happened. For the three simulations inundation is classified as flood at the depth of $0.05 \mathrm{~m}$ thus the temporal inundation with depth greater than 0.05 is included as flood. Figure 3-5 are the max flood map for the three simulation date after adjustment. According the figures can be seen the maximum flood depth is greater than $3 \mathrm{~m}$ in certain area however the rainfall inputs are relatively small compare to rainfall of return period scenarios. From this point, we can expect 
that the flood area and max flood depth of return period scenario simulations will be greater than this.

The simulation also used the multiplying factors for $\mathrm{K}_{\mathrm{sat}}$ and Theta $\mathrm{i}_{\mathrm{i}}$ that had been obtained at previous section. Generally there are increasing in total runoff and total infiltration correspond to increasing of rainfall. However the interception either from vegetation or house cover (rooftop) does not correspond to the rainfall input. The increasing is relatively small compare to infiltration or runoff. It is highly affected by unchanged capacity of land cover especially vegetation and rooftop to intercept water.

Figure 6 is the hydrograph of simulations for 3 rainfall intensity scenarios after validation while Table 9 is the results summary of all variables simulated by OpenLISEM with each rainfall input. There is significant increasing in discharges highly correlated with increasing of rainfall intensity. The peak of hydrograph for higher rainfall intensity is also elongated which shows that the catchment can maintain to produce high discharge in longer period of time meanwhile the channel has constant capacity. As the result some of the water overflows and higher rainfall intensity shows wider and deeper inundation area. Figure 7-9 are the maximum flood maps for each return period during simulation.

Dense vegetation such as forest, plantation and shrubs (directed from visual interpretation) infiltrates more water and intercept more water than other land covers. Nevertheless interception values from any intensity scenario are relatively less than other process. Crops with sparser canopy cover and lower infiltration rate drive higher runoff. The lower velocity at the crops area also increasing the possibility for water stays longer and inundate.

Thing should be noted that this simulation is a single storm simulation that produces single flood with assumption there are no influences of other storms that

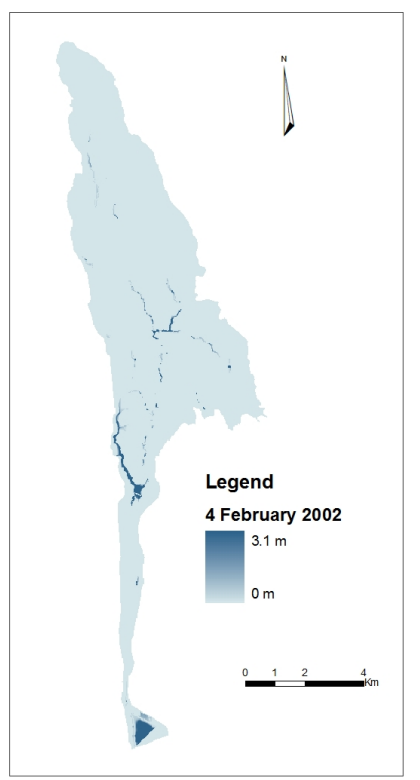

Figure 3. Flood map at 4-Feb-02

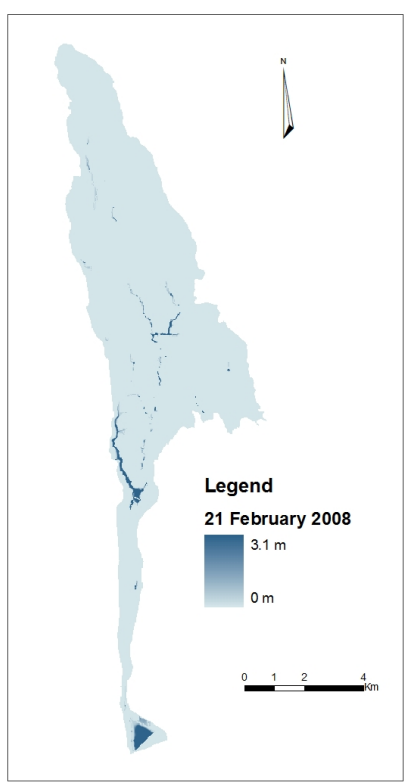

Figure 4. Flood map at 21-Feb-08

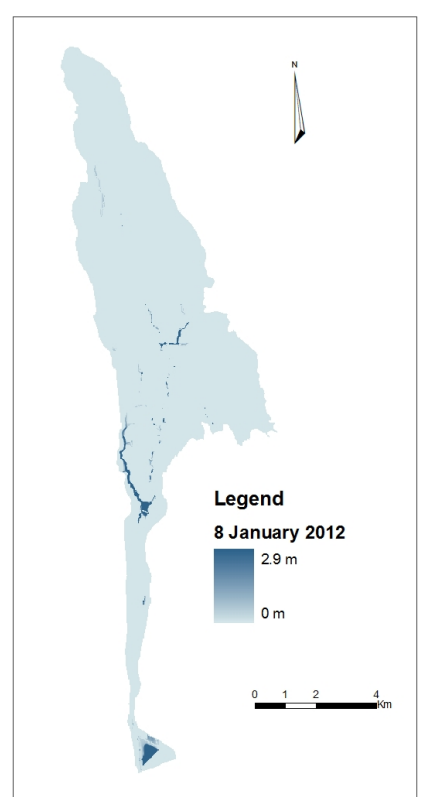

Figure 5. Flood map at 8-Jan-12

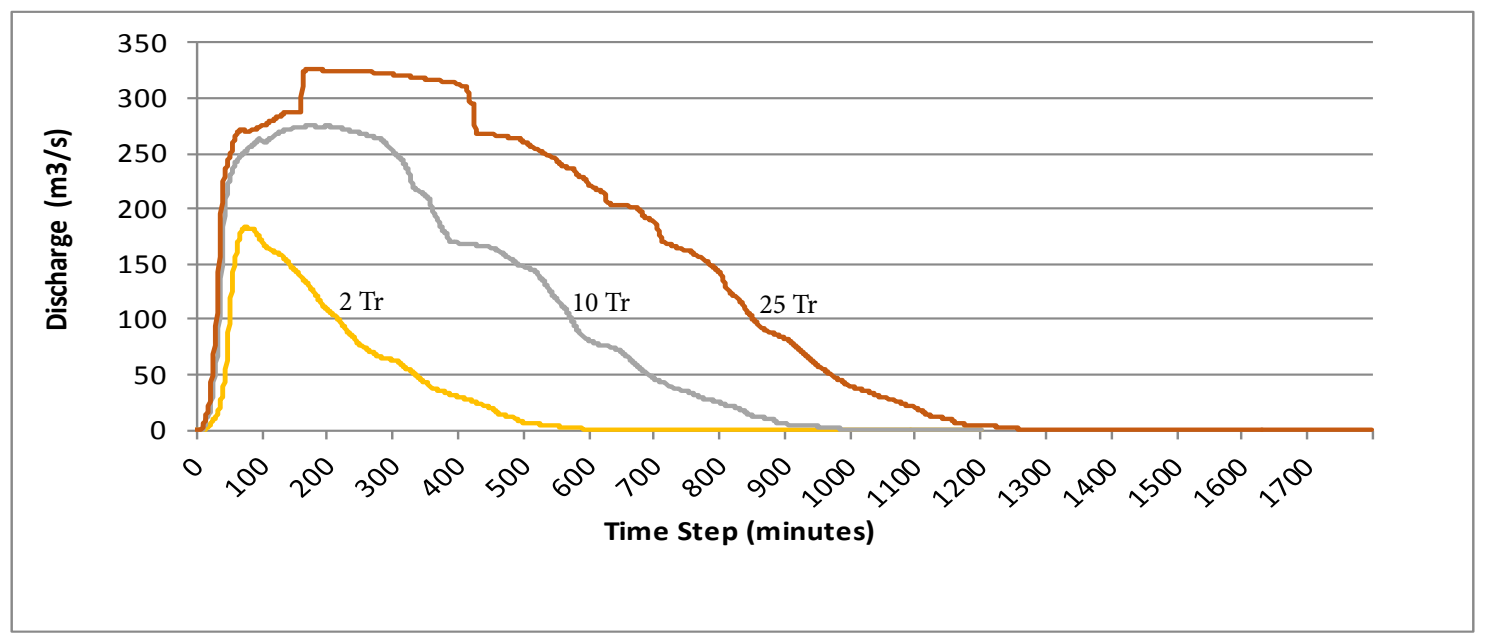

Figure 6. Hydrograph for 2 years, 10 years and 25 years return period 
Table 9. Results Summary for 3 Return Period Scenario

\begin{tabular}{lrrr}
\hline Simulation Results & \multicolumn{3}{c}{ Return Period } \\
\cline { 2 - 4 } & 2 Years & 10 Years & 25 Years \\
\hline Total rainfall $(\mathrm{mm})$ & 92.51 & 161.71 & 196.54 \\
Total discharge $(\mathrm{mm})$ & 42.10 & 99.54 & 142.26 \\
Total interception $(\mathrm{mm})$ : & 0.00 & 0.01 & 0.01 \\
Total House interception $(\mathrm{mm})$ & 0.08 & 0.08 & 0.08 \\
Total infiltration $(\mathrm{mm})$ & 45.22 & 55.56 & 61.63 \\
Surface storage $(\mathrm{mm})$ & 0.02 & 0.03 & 0.03 \\
Water in runoff $+\mathrm{channel}(\mathrm{mm})$ & 0.10 & 0.26 & 0.10 \\
Total discharge $\left(\mathrm{m}^{3}\right)$ & 2367290.70 & 5596843.52 & 7998667.76 \\
Peak discharge $\left(\mathrm{m}^{3} / \mathrm{s}\right)$ & 136.08 & 139.32 & 141.25 \\
Peak time rainfall $(\mathrm{min})$ & 1.00 & 1.00 & 1.00 \\
Peak time discharge $(\mathrm{min})$ & 201.00 & 250.00 & 212.00 \\
Discharge/Rainfall $(\%)$ & 45.51 & 61.55 & 72.38 \\
Flood volume $(\mathrm{max}$ level $)\left(\mathrm{m}^{3}\right)$ & 1539136.27 & 4868086.60 & 6305845.61 \\
Flood area $($ max level $)\left(\mathrm{m}^{2}\right)$ & 2853903.02 & 6962866.90 & 8050355.97 \\
\hline
\end{tabular}

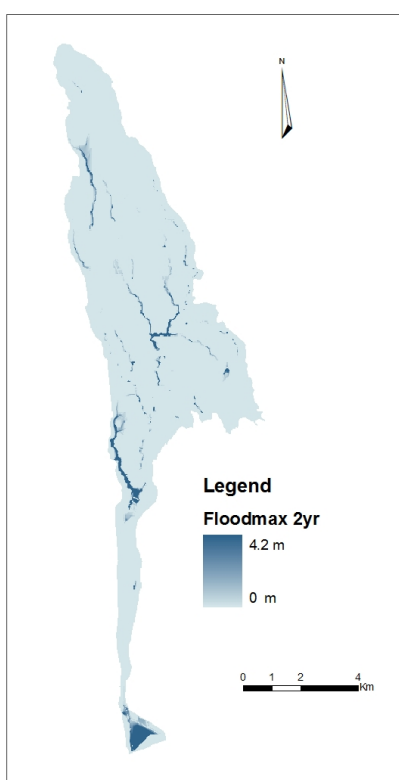

Figure 7. Flood map for 2 years Tr scenario

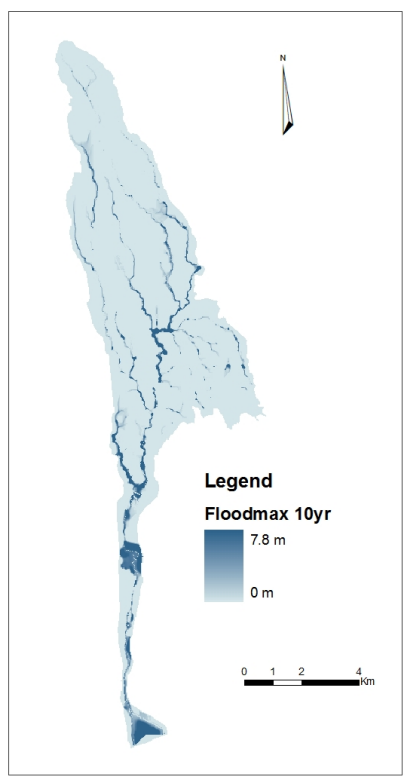

Figure 8. Flood map for 10 years $\mathrm{Tr}$ scenario

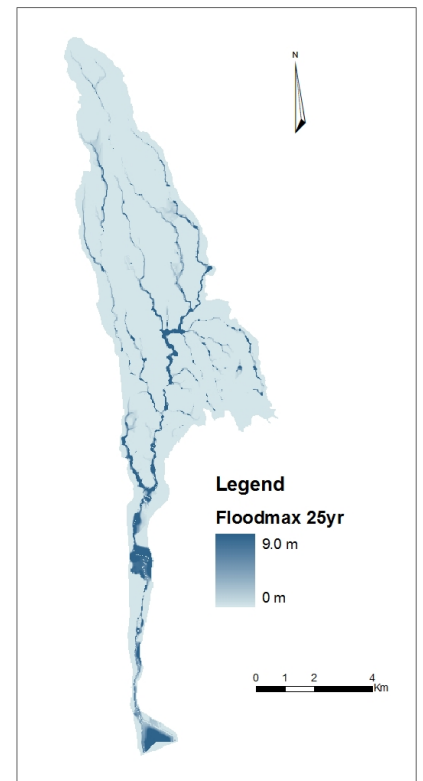

Figure 9. Flood map for 25 years Tr scenario might be happen at the catchment, before or after or during the simulation. If the time step of simulation is extended, the water that inundated at the catchment will recede through run off to lower area or channel. It sometimes happen factually in Logung Sub-catchment after a single storm, the flood will stay for a day and recede the next day. Though at the peak of wet season when the storms happen every day or sometimes several times a day the flood stay longer with higher intensity. According to the farmers, this type of flood with long time inundation is more harmful to crops than the flood than only stay for couple of hour. This maximum flood depth map will be used for flood risk assessment as flood hazard maps. Before these maps used for risk assessment the flood map will be classified according to the flood depth.

\section{Conclusion}

OpenLISEM as physical model to simulate soil and hydrological process can be used to assess flash flood hazard even though requires many specific data inputs. There are 3 return period scenarios represents 
the rainfall intensity in Logung Sub-catchment. The calibration was done by changing the $\mathrm{K}_{\text {sat }}$ and Theta values. Flood and water inundation are highly related to land cover that improves runoff. Crops with low infiltration rate and sparser coverage are expected increasing runoff. Rainfall intensity also strongly affects the runoff, peak discharge, total discharge and inundation area, but does not affect the peak time of discharge.

\section{Acknowledgment}

Acknowledgments are delivered to Ministry of Education for the financial support during writer's master degree on Geo-Information for Spatial Planning and Disaster Risk Management, double degree Program between Graduate School of Gadjah Mada University and University of Twente and to Lembaga Pengelola Dana Pendidikan, Ministry of Finance for financial support during this research. Acknowledgments are also delivered BBWS Pemali Juwana, BPDAS Jatrun Seluna, PSDA Seluna, all farmer and village officers at Bulungcangkring, Sadang, Jojo and Hadiwarno Village for the helps related to the references and data collections.

\section{References}

Allen, R. G., L. S. Pereira, et al. (2000). FAO Irrigation and Drainage Paper No 56 Crop Evapotranspiration. Rome, FAO.

Baver, L. D. (1956). Soil Physics. Tokyo, Charles E. Tutle Company.

BBWS Pemali Juwana (2004). Detail Plan of Juwana River Flood Risk Management. Semarang, Department of Public Work.

Buckman, H. O. and N. C. Brady (1960). The Nature and Properties of Soils. New York, The Macmillan Company.

Chow, V. T. (1959). Open-Channel Hydraulics. Tokyo, McGraw-Hill Kogakhusa.

Clapp, R. B. and G. M. Hornberger (1978). "Empirical equations for some soil hydraulic properties." Water Resources Research 14(4): 601-604.

De Roo, A. P. J. (1996). The Lisem Project: An Introduction, Hydrological Processes 10(8): 10211025.

Offermans, et al. (1996), Lisem:

A Single-Event, Physically Based Hydrological and Soil Erosion Model For Drainage Basins. II: Sensitivity Analysis, Validation and Application, Hydrological Processes 10(8): 1119-1126.

Wesseling, et al. (1996). Lisem: A Single-Event Physically Based Hydrological and Soil Erosion Model For Drainage Basins. I: Theory, Input and Output." Hydrological Processes 10(8): 1107-1117.

EM-DAT. (2015), Disaster List, cited in http://www. emdat.be/database [Retrieved 8 May, 2015].
FAO (1980). Drainage Design Factors. FAO Irrigation and Drainage Paper No. 38. Roma.

Hessel, R., V. Jetten, et al. (2003). "Calibration of the LISEM model for a small Loess Plateau catchment." Catena 54(1-2): 235-254.

Istiarto and G. D. Wibowo (2007). Juwana River Flood Control System, Dinamika Teknik Sipil 7(2): 191197.

Jetten, V., G. Govers, et al. (2003). Erosion models: quality of spatial predictions, Hydrological Processes 17(5): 887-900.

Koutroulis, A. G. and I. K. Tsanis (2010), A method for estimating flash flood peak discharge in a poorly gauged basin: Case study for the 13-14 January 1994 flood, Giofiros basin, Crete, Greece, Journal of Hydrology 385(1-4): 150-164.

McCuen, R. H. (1998), Hydrologic Analysis and Design, Prentice Hall PTR.

Mulyaningsih, S., S. Bronto, et al. (2008). Study of Vulcanic Formation of Patiayam Mountain in Jekulo Sub-District, Kudus Regency, Central Java, Jurnal Geologi Indonesia 3(2): 14.

Santoso, H. (2013), Study of the effects of River Normalization to Reducing Juana River Flood Risk in Pati Regency and Kudus Regency Central Java. Msc, Institut Teknologi Bandung.

Saxton, K. E. and W. J. Rawls (2006), Soil Water Characteristic Estimates by Texture and Organic Matter for Hydrologic Solutions, Soil Science Society of America Journal 70: 10.

Setiawan, A. (2009). Study Of Land Use Change Effect on The Runoff Using LISEM (Limburg Soil Erosion Model) Rainfall-Runoff Model. Msc, UGM-ITC.

Setiono, B. (2006). Landcover Changes Detection Using Landsat ETM+ Imagery in Juwana Catchment, Central Java. Bachelor Thesis, Bogor Agricultural University.

Sosrodarsono, S. and K. Takeda (1977). Manual on Hydrology. Jakarta, Pradyna Paramita.

Sui, J. (2005). “Estimation of Design Flood Hydrograph for an Ungauged Watershed." Water Resources Management 19(6): 813-830.

UNISDR (2009). 2009 UNISDR Terminology on Disaster Risk Reduction. Geneva, UNISDR.

van Diepen, C. A., J. Wolf, et al. (1989). "WOFOST: a simulation model of crop production." Soil Use and Management 5(1): 16-24.

van Noordwijk, M., A. Farida, et al. (2003). Agroforestry and Watershed Functions of Tropical Land Use Mosaics. 2nd Asia Pacific Training Workshop on Ecohydrology: Integrating Ecohydrology and Phytotechnology into Workplans of Government, Private and Multinational Companies. Cibinong, World Agroforestry Centre - ICRAF, SEA Regional Office: 1-10.

Widyana, N. (2010). Identification of Flood Causes in Juwana Catchment. Semarang, BPDAS PemaliJratun. 